\title{
Obtaining employee commitment to living the brand of the organisation
}

\author{
G. Boyd \\ Wits Business School, University of the Witwatersrand, \\ PO Box 98, Wits 2050, Republic of South Africa \\ M. Sutherland* \\ Gordon Institute of Business Science, University of Pretoria \\ PO Box 787602, Sandton,2146, Republic of South Africa \\ sutherlandm@gibs.co.za
}

Received August 2005

\begin{abstract}
In the competitive business environment, brand management is viewed as a critical success factor. The importance of building a brand-centric organisation in which employees are ambassadors for the brand is often espoused, but there has been little empirical evidence of how managers should set about achieving this. This exploratory qualitative study consisted of four case studies in organisations where employees are acknowledged to 'live the brand' to obtain empirical evidence of those factors that influenced employee performance. The study uncovered six key practices that managers should implement in an integrated manner when driving an intervention to enable employees to live the brand. The findings also contradict some of the human resource literature in what was found to be unimportant.
\end{abstract}

*To whom all correspondence should be addressed.

\section{Introduction}

In a competitive business environment companies have to leverage every possible advantage to be successful. One of the ways that they attempt to do this is through the company brand strategy (Kotler, 2003). Spark (2004: 6) believes 'the value of a brand correlates directly to the value of the business'. Brands assist with the identification of a specific product, signal quality, offer a promise of performance with lower risks, and are a source of competitive advantage (Keller, 2003). The concept of a brand has however undergone a rapid evolution in recent years. No longer are brands just visible or emotional symbols. Rather, they define the relationships with all of the company's key stakeholders, including employees (Spark, 2004).

Given the complex nature of brands and branding, many organisations often fail to consider the role that employees can play in realising a company's brand strategy. Whether it's the actual impact on customer service levels or the influence on stakeholder perceptions, employee behaviour impacts on company brand perceptions and ultimately affects the bottom line (James, 2000; Mitchell, 2002; Beagrie, 2003; Fram \& McCarthy, 2003; Drizin in Larsen, 2003; Simms, 2003).

Influencing employee attitudes and behaviour should be an integral part of a company's overall branding strategy. As Payne, Christopher, Clark and Peck (2001) say organisations should have the goal to re-orientate the entire business to face the market. When done properly, it can generate higher levels of employee brand loyalty, which can translate into incremental sales and increased profits, whilst simultaneously differentiating oneself from the competition (James, 2000; Mitchell, 2002; Beagrie, 2003; Fram \& McCarthy, 2003; Simms, 2003). A higher level of employee brand loyalty is related to higher levels of employee job satisfaction (Fram \& McCarthy, 2003).

\section{The research problem}

The purpose of this study was to determine the key success factors in obtaining employee commitment to living the brand of the organisation, by reviewing literature on the topic and using the scientific case study method of Yin (1984) to gather empirical data. There are numerous articles published on internal marketing to employees (James, 2000; Mitchell, 2002; Beagrie, 2003; Simms, 2003), and many companies aspire to getting their employees to live the brand, however this is little empirical evidence of how to achieve this.

\section{Literature review}

'Living the brand' of the organisation means that an employee must behave in a way that is representative of that company's brand, values and culture. Bendapudi and Bendapudi (2005:124) suggest that companies should '...consider employees their living brand and devote a great deal of time and energy to training and developing them so that they reflect the brand's core values'. This is often referred to as employee branding or human capital branding. 
Mitchell (2002) believes that organisations trying to achieve employee commitment to living the brand of the organisation need to create an emotional connection with employees to make the brand come alive for them in order to persuade them to align their values and behaviours with that of the company's brand. Human resource managers strive to achieve employee engagement which Das (2003) proposes is driven by six factors: reward, recognition, relationships, opportunity, environment and leadership. He says engagement consists of three key elements: 'say' (where employees speak positively about where they work); 'stay' (not only do employees stay, but show this by wanting to contribute to the good of the group) and 'strive' (where an employee goes the 'extra mile' in contributing to the organisation). These factors are closely related to employees acting as brand ambassadors.

Czaplewskim, Ferguson and Milliman (2001:14) believe that internal marketing is 'an important way to obtain, develop, motivate, and retain skilled staff and energised employees who in turn provide high quality service'. Beagrie (2003) contends that internal marketing is the process of motivating employees to change their behaviours and thinking in order to achieve organisational goals. Many of the authors also allude to the concept that internal marketing is the process of viewing employees as customers providing a vital link in the implementation of any marketing strategy to better serve the organisation's customers (Drummond \& Ensor, 1999).

The essence of performance management systems is a shared process between managers and the people they manage based on the principle of a psychological contract (Armstrong, 2000). Philpott and Sheppard in Armstrong (2000: 5) state the purpose of performance management 'is to establish a culture in which individuals and groups take responsibility for the continuous improvement of business processes and their own skills and contributions'. Mullich (2003) contends that employees need to be evaluated, rated and given feedback on how they performed against their goals and the company's goals. This is supported by Welbourne (2003) who believes that in order for employee engagement to be a success organisations need to measure employee engagement frequently and in multiple ways.

Incentives and rewards need to be aligned with the achievement of personal, departmental and company goals. McDermott (2002:42) defines an incentive as 'a way of motivating our employees to perform at a level that is above what we expect as normal'. Performance management is the primary means of evaluating employees and providing feedback to them. Given the close link between the employment relationship and obtaining employee commitment to living the brand of the organisation, the implication is that performance management practices need to be evident, for employee branding to be a success.

Employee loyalty is another important aspect in building the employment relationship, as 'loyal employees make up the core of a successful business, managing the company, designing products and services, selling new business and interacting with customers everyday' (Larsen, 2003:10). Loyal employees are also more likely to engage in brand championship, which is the positive 'pass-along' effect on sales and profits, as a result of others coming into contact with a firm's internal brand champions (Fram \& McCarthy, 2003). Brand championship offers the opportunity to increase company goodwill in the communities in which the firm operates, when employees represent themselves to others as supporters of their company, developing a positive image of the company.

Given the emphasis placed on human capital in the new world of work, it is understandable that organisations have begun to aggressively compete for talent. According to Czaplewski et al. (2001) when attracting new employees, companies should be more concerned with hiring people with the right attitude because attitudes are more difficult to change, whilst skills can always be taught. Employers of choice are those organisations that outperform their competition to attract, develop, and retain people with business related talent. They achieve this recognition through innovative and compelling human resource programmes that benefit both employees and their organisations alike (Copeland, 2000). Greatplacetowork (2004) delineates what is needed in order to create a great working environment, listing five dimensions; credibility, respect, fairness, pride and camaraderie.

James (2000), Mitchell (2002) and Beagrie (2003) contend that in order for employee branding to occur it has to be made a key business objective. The authors believe this starts with senior management. They have to offer a clear vision worth pursuing, which reinforces the big picture to employees. Mullich (2003) maintains that human capital branding can only occur when employees can see that their efforts dovetail with the company's corporate goals. He argues that people talk about aligning corporate, departmental and employee goals, but few actually do it.

A starting point for making the brand come alive for employees is through an understanding of who the internal customer is. Mullich (2003) believes that while most firms define themselves by the products and services they offer, they are actually defined by the productivity, quality and service of their human capital, namely the performance of their employees. He believes a company's true persona begins from within, so if employees cannot project the message that the company is trying to convey, that message will not resonate with customers. Mitchell (2002) supports this view noting that employees must know everything customers know about the company, long before customers know. Employees must therefore be treated like customers in order for them to believe in the company's brand. Employees need to be seen as the internal market within the organization as part of the larger relationship marketing plan (Payne et al., 2001).

Experiences are unique in that they are able to convey intangible aspects (like feelings), making it an ideal tool to assist in conveying a company's brand values, which are often intangible in nature (Pine \& Gilmore, 1998). Experiences have for some time now been used by leading edge companies to further differentiate themselves from the competition. What companies have begun to realise is that experiences are not for the exclusivity of customers, but are 
also very useful in making the company's brand or big ideas come alive for employees (Pine \& Gilmore, 1998).

Viewed in another way, internal marketing can also be considered the communication platform for the employment relationship and therefore the platform for obtaining employee commitment to living the brand of the organisation. Beagrie (2003) believes that the best way to do this is through employing the same persuasive methods of communication that companies employ to market products and services externally. Although Mitchell (2002) supports this view, proposing that internal marketing and external marketing should be linked ensuring that employees hear the same messages that customers do. Hail in Simms (2003) contends the best solution is to undertake a joint marketing/human resources approach, where employees are aligned behind the brand positioning and promise, and have the systems and processes in place to implement them. Companies that are good at internal marketing treat the consumer brand and the employee brand as two sides of the same coin and integrate their communications accordingly.

Internal marketing has a number of other $\mathrm{HR}$ and organisational benefits, including high levels of employee satisfaction, improved retention rates, reduced absenteeism and wider acceptance of any change programme (Beagrie, 2003). Internal marketing can therefore generate higher levels of employee brand loyalty that can translate into incremental sales and profits. Internal marketing therefore has a key role to play in obtaining employee commitment to living the brand of the organisation.

Organisational culture is an important concept in this research as organisations wanting to obtain employee commitment to living the brand of the organisation often have to change company culture (Ind, 2004). Organisational culture as defined by Williams (1989:11) is 'the commonly held and relatively stable beliefs and values that exist within an organisation'. It is often defined as 'the way people think about things around here'. This includes patterns of behaviour in the organisation, the rites, rituals and symbols (Williams, 1989). Getting employees to live the brand is a major organisational initiative and this study set out to determine what some of the key building blocks of an appropriate culture would be.

\section{Conclusion to literature review}

While there is much written about traditional marketing and HR practices, the area of employee branding remains an exciting new concept. Although a fair amount of material exists on the topic, few authors have managed to integrate the themes and/or to come up with specific recommendations as how to implement these employee branding initiatives together. One reason for this may be that the topic requires the merger of concepts from marketing and human resource practices, which is not common as organisational divisions often work in isolation. Despite the material available on employee branding there remains little integrated empirical information on successful implementation of managing employee branding in South Africa.

\section{Propositions}

From the preceding literature the following propositions were constructed:

Companies that successfully obtain employee commitment to living the brand of the organisation have the following characteristics:

- $\quad$ They make employee branding a key business priority (James, 2000; Mitchell, 2002; Beagrie, 2003).

- They communicate a clear set of values to their employees, and live by them (Ind, 2004).

- They compete for talented employees and focus on their needs (Czaplewski et al., 2001).

- $\quad$ They have an internal employee branding programme which builds employee loyalty through: informing, motivating, energising and engaging employees (Larsen, 2003; Robbins, 2003).

- $\quad$ They integrate measurement and reward criteria into their overall performance management system to track, evaluate and reward employee commitment to living the brand of the organisation (Armstrong, 2000; Mullich, 2003).

- $\quad$ They monitor company culture (beliefs and values) on an on going basis and are prepared to effect changes when necessary (Williams, 1989).

The objective of the study was to verify and evaluate whether the propositions posed were in fact correct, or whether there were other factors that still needed to be considered.

\section{Methodology}

The study was conducted in two phases. Phase one was conducted through personal interviews with five experts in the field of employee branding in order to identify suitable case study companies. These experts were consultants on branding and academics who consult in this field. They were asked to identify four South African organisations where employees 'live the brand'. After consolidating this information four organisations were identified. Bryman (1989) recommends that between one and five organisations are appropriate in cases where the primary focus is on qualitative interviews.

Access was then obtained via the HR Managers. The organisations were: An investment bank having over 1000 employees, which has won the best company to work for award; a corporate bank with 650 employees; a large manufacturer of alcoholic beverages with 5000 employees which had also won the best company to work for award; a telecommunications company with 3500 employees. All of these companies' brands have wide national public recognition value. 
Phase two consisted of four case studies combining qualitative and quantitative research. Yin (1984:23) defines a case study as, 'an empirical inquiry that investigates a contemporary phenomenon within its real-life context; when the boundaries between the phenomenon and context are not clearly evident; and in which multiple sources of evidence are used'.

Participants. A modified quota sampling technique (Leedy \& Ormrod, 2001) was used to select 8 employees in each organisation divided equally between managerial employees and non-managerial employees, and from human resource, marketing and finance departments. Only candidates that had been employed for a minimum period of 12 months were considered. The Human Resource managers were also interviewed. Thus a total of 51 respondents were interviewed in the two stages, which is considered sufficient for an exploratory study.

Methods of data gathering. Three sources of data were used in the collection process. Semi-structured personal interviewing using a questionnaire was the primary method used to gather data. This data was complemented by observational techniques by the researcher whilst interviewing and spending time on-site. At the beginning of each case study the interviewer completed a checklist together with the HR manager to document any visible signs of employee branding. In order to confirm the validity of the study process, triangulation was thus used (Stake, 1995). It allowed for the collection of data from a number of different sources, thus substantiating the findings and conclusions made in the study. This was done through the convergence of the evidence (Yin, 1984) in that 'many separate pieces of information must all point to the same conclusion' (Leedy \& Ormrod, 2001:150).

The questionnaire used in the interviews was divided into qualitative and quantitative sections. Section A posed three questions; a quantitative question asking them to rank the degree to which employees are encouraged to live the brand (results in Table 1); two open-ended questions, exploring the respondents' views as to why and how they thought the company did this (results in Table 2). Section B of the questionnaire required the respondents to rate forty six statements, developed from the literature, as to the extent to which the respondent experienced that factor in the organisation, using a five point Likert rating scale (results in Table 3). The questionnaire was pre-tested and corrected for design errors.

Analysis of the data. A large proportion of the data collected was qualitative in nature, and content analysis was used to analyse that data. Leedy and Ormrod (2001:155) define it as 'a detailed and systematic examination of the contents of a particular body of material for the purpose of identifying patterns, themes, or biases' which measures the semantic content or the 'what' of a message. Quantitative analysis was used to summarise and evaluate the responses from section $\mathrm{B}$ of the questionnaire. Thereafter responses from section $A$ and $B$, together with the researcher's checklist (results in Table 4), were used to triangulate the data.

\section{Limitations}

Given the qualitative nature of the case study method, as well as the study being conducted in the interpretive paradigm, certain limitations apply: Only limited generalisations can be made as the purpose of case study research is to add to theory-building rather than to generalise to a population. Judgemental sampling was used to arrive at which companies were researched as case studies. Quota sampling was used to determine which respondents in each organisation are to be interviewed (Leedy \& Ormrod, 2001). These limitations may impact on the validity and reliability of the study.

\section{Results}

The following table presents the responses to the question 'Do you think this organisation actively encourages employees to live the brand of the organisation?'

\section{Table 1: Does this organisation encourage employees to live the brand?}

\begin{tabular}{c|c|c|c|c}
\hline $\begin{array}{c}\text { Strongly } \\
\text { agree }\end{array}$ & Agree & $\begin{array}{c}\text { Neither } \\
\text { agree or } \\
\text { disagree }\end{array}$ & Disagree & $\begin{array}{c}\text { Strongly } \\
\text { disagree }\end{array}$ \\
\hline 16 & 15 & 1 & 0 & 0 \\
\hline
\end{tabular}

The above table confirms that the study in these four companies was justified, given their strong commitment to living the brand of the organisation.

The following table gives the results of the content analyses to the questions 'why' employees thought their companies actively encouraged them to live the brand of their organisation and 'how' employees thought their companies encouraged them.

Table 3 presents the rank ordered results from section B of the questionnaire. The ranking was done using the scores from the 'strongly agree' column first and thereafter scores from the 'agree' column.

In order to assist with triangulation and validation of the study information, the researcher gathered evidence of employee branding in the individual companies whilst on site. Table 4 highlights how much these organisations are doing, to strive to obtain employee commitment to living the brand of their organisation.

\section{Discussion}

In order to interpret the results the key themes emerging from the tables were considered in combination. Firstly, each table was investigated for possible themes. Thereafter common themes across the tables were merged together to answer the propositions. 
Table 2: Consolidated content analysis

\begin{tabular}{|c|c|c|}
\hline Ranking & 'WHY' - key constructs established & $\begin{array}{c}\begin{array}{c}\text { No. of times } \\
\text { mentioned }\end{array} \\
\end{array}$ \\
\hline 1 & The company makes a big point of encouraging us to live the brand (communication). & 13 \\
\hline 2 & To create a sense of pride, ownership \& commitment (loyalty). & 10 \\
\hline 2 & $\begin{array}{l}\text { Competitive advantage and differentiation in market. It's a good way for the company to sell } \\
\text { itself (best company to work for). }\end{array}$ & 10 \\
\hline 3 & $\begin{array}{l}\text { To provide an identity for the company and keep the culture intact (entrench company's } \\
\text { philosophy and values). }\end{array}$ & 8 \\
\hline 4 & The development of employees and the importance the company places on staff. & 6 \\
\hline 5 & To encourage entrepreneurship, motivation and have happier staff. & 5 \\
\hline 6 & $\begin{array}{l}\text { To get staff to understand and believe in the company's brands (adds to the power of brand } \\
\text { equity that you currently have). }\end{array}$ & 3 \\
\hline 6 & To achieve alignment between the company and its people. & 3 \\
\hline 7 & The ability to give your own input. & 2 \\
\hline Ranking & 'HOW' - Key constructs established & $\begin{array}{c}\text { No. of times } \\
\text { mentioned }\end{array}$ \\
\hline 1 & $\begin{array}{l}\text { Communication (Intranet, focus groups, satellite broadcasts, road shows, feedback sessions, } \\
\text { company magazines, general interaction and big picture communication, induction) }\end{array}$ & 31 \\
\hline 2 & Through internal campaigns, projects and policies & 10 \\
\hline 3 & $\begin{array}{l}\text { By encouraging participation and bringing staff together. (Functions, events, conferences, } \\
\text { participation in company commercial, invitations to sporting events.) }\end{array}$ & 7 \\
\hline 3 & $\begin{array}{l}\text { Open door management style, no discrimination, freedom to perform and support given to } \\
\text { employees. }\end{array}$ & 7 \\
\hline 4 & $\begin{array}{l}\text { Through training \& development, by constantly pushing employees and making you think you } \\
\text { are the best of the best. Constant nurturing of employees. }\end{array}$ & 6 \\
\hline 5 & Pay / share options / bonuses. & 5 \\
\hline 6 & Through actual values and non-stated culture. & 3 \\
\hline 7 & Through the display of visual value statements. & 2 \\
\hline
\end{tabular}

Table 3: Factors present in the organisation

\begin{tabular}{|c|c|c|c|c|c|c|}
\hline Rank & $\begin{array}{l}\text { Factors which you experience in your } \\
\text { organisation. }\end{array}$ & $\begin{array}{l}\text { Strongly } \\
\text { agree }\end{array}$ & Agree & $\begin{array}{l}\text { Neither } \\
\text { agree or } \\
\text { disagree }\end{array}$ & Disagree & $\begin{array}{l}\text { Strongly } \\
\text { disagree }\end{array}$ \\
\hline 1 & A brand is a valuable asset. & 25 & 7 & $\mathbf{0}$ & $\mathbf{0}$ & $\mathbf{0}$ \\
\hline 2 & $\begin{array}{l}\text { I am encouraged to learn and develop at this } \\
\text { company. }\end{array}$ & 21 & 11 & $\mathbf{0}$ & $\mathbf{0}$ & $\mathbf{0}$ \\
\hline 3 & Change is something we are used to. & 20 & 10 & 2 & $\mathbf{0}$ & $\mathbf{0}$ \\
\hline 4 & $\begin{array}{l}\text { The company's vision and values are clearly } \\
\text { communicated to me. }\end{array}$ & 19 & 12 & 1 & $\mathbf{0}$ & $\mathbf{0}$ \\
\hline 5 & I'm proud to wear company branded items. & 19 & 12 & $\mathbf{0}$ & 1 & $\mathbf{0}$ \\
\hline 6 & $\begin{array}{l}\text { This organisation has a unique culture that I can } \\
\text { identify with. }\end{array}$ & 19 & 11 & 2 & $\mathbf{0}$ & $\mathbf{0}$ \\
\hline 7 & $\begin{array}{l}\text { This company measures employees on their work } \\
\text { performance. }\end{array}$ & 18 & 14 & $\mathbf{0}$ & $\mathbf{0}$ & $\mathbf{0}$ \\
\hline 8 & $\begin{array}{l}\text { It is a top business priority to get employees to live } \\
\text { the brand of the organisation. }\end{array}$ & 18 & 13 & 1 & $\mathbf{0}$ & $\mathbf{0}$ \\
\hline 9 & I feel loyalty for this organisation. & 18 & 13 & 1 & $\mathbf{0}$ & $\mathbf{0}$ \\
\hline 10 & $\begin{array}{l}\text { It is usual for the company to hold themed events } \\
\text { for employees. }\end{array}$ & 18 & 11 & 2 & $\mathbf{0}$ & 1 \\
\hline 11 & $\begin{array}{l}\text { This is one of the best companies to work for in } \\
\text { South Africa. }\end{array}$ & 18 & 10 & 2 & 2 & $\mathbf{0}$ \\
\hline 12 & $\begin{array}{l}\text { I am willing to put in a great deal of effort beyond } \\
\text { what's normally expected to make this } \\
\text { organisation successful. }\end{array}$ & 17 & 13 & 1 & 1 & $\mathbf{0}$ \\
\hline 13 & $\begin{array}{l}\text { I love the buzz and high levels of energy at this } \\
\text { company. }\end{array}$ & 17 & 13 & 1 & 1 & $\mathbf{0}$ \\
\hline 14 & $\begin{array}{l}\text { The company's brand or brands are known by all } \\
\text { employees. }\end{array}$ & 17 & 12 & 2 & 1 & $\mathbf{0}$ \\
\hline 15 & $\begin{array}{l}\text { I have branded office stationery or merchandise } \\
\text { which the company gave me. }\end{array}$ & 17 & 11 & 2 & 2 & $\mathbf{0}$ \\
\hline 16 & $\begin{array}{l}\text { I understand how I contribute to the overall } \\
\text { success of this company. }\end{array}$ & 16 & 16 & $\mathbf{0}$ & $\mathbf{0}$ & $\mathbf{0}$ \\
\hline 17 & $\begin{array}{l}\text { Many aspects of my work are used to determine } \\
\text { my overall performance assessment. }\end{array}$ & 16 & 15 & 1 & $\mathbf{0}$ & $\mathbf{0}$ \\
\hline 18 & I understand what our company's brands are & 15 & 17 & $\mathbf{0}$ & $\mathbf{0}$ & $\mathbf{0}$ \\
\hline
\end{tabular}




\begin{tabular}{|c|c|c|c|c|c|c|}
\hline Rank & $\begin{array}{l}\text { Factors which you experience in your } \\
\text { organisation. }\end{array}$ & $\begin{array}{l}\text { Strongly } \\
\text { agree }\end{array}$ & Agree & $\begin{array}{l}\text { Neither } \\
\text { agree or } \\
\text { disagree }\end{array}$ & Disagree & $\begin{array}{l}\text { Strongly } \\
\text { disagree }\end{array}$ \\
\hline & about. & & & & & \\
\hline 19 & This is an exciting place to work. & 15 & 16 & $\mathbf{0}$ & 1 & $\mathbf{0}$ \\
\hline 20 & $\begin{array}{l}\text { I sell this organisation to my friends and } \\
\text { recommend that they use our products and brands. }\end{array}$ & 15 & 14 & 2 & $\mathbf{0}$ & 1 \\
\hline 21 & $\begin{array}{l}\text { This company recognises its people for the work } \\
\text { they do. }\end{array}$ & 15 & 13 & $\mathbf{0}$ & 4 & $\mathbf{0}$ \\
\hline 22 & There is pride and camaraderie in this company. & 14 & 18 & $\mathbf{0}$ & $\mathbf{0}$ & $\mathbf{0}$ \\
\hline 23 & $\begin{array}{l}\text { Employees in this company go the extra mile for } \\
\text { customers. }\end{array}$ & 14 & 9 & 4 & 5 & 0 \\
\hline 24 & I believe I make a difference at this company. & 13 & 18 & $\mathbf{0}$ & 1 & $\mathbf{0}$ \\
\hline 25 & $\begin{array}{l}\text { Senior executives live the brand of the } \\
\text { organisation. }\end{array}$ & 13 & 16 & 1 & 2 & $\mathbf{0}$ \\
\hline 26 & This company treats its employees fairly. & 13 & 16 & 2 & 1 & $\mathbf{0}$ \\
\hline 27 & $\begin{array}{l}\text { This company always lets me know what's going } \\
\text { on. I don't usually find things out from my friends. }\end{array}$ & 13 & 16 & 0 & 3 & $\mathbf{0}$ \\
\hline 28 & I can participate in decisions that affect me. & 13 & 15 & 1 & 3 & $\mathbf{0}$ \\
\hline 29 & $\begin{array}{l}\text { Management really care whether employees are } \\
\text { happy at this organisation. }\end{array}$ & 13 & 14 & 2 & 1 & 2 \\
\hline 30 & $\begin{array}{l}\text { We have workshops to ensure that our } \\
\text { department's goals are in line with those of the } \\
\text { company's. }\end{array}$ & 13 & 13 & 2 & 4 & $\mathbf{0}$ \\
\hline 31 & Big changes are implemented professionally. & 12 & 18 & 1 & $\mathbf{0}$ & 1 \\
\hline 32 & $\begin{array}{l}\text { I feel that my values and the organisation's values } \\
\text { are the same. }\end{array}$ & 12 & 17 & 1 & 1 & 1 \\
\hline 33 & $\begin{array}{l}\text { This company has many opportunities for } \\
\text { advancement. }\end{array}$ & 12 & 17 & 3 & $\mathbf{0}$ & $\mathbf{0}$ \\
\hline 34 & $\begin{array}{l}\text { This company has an internal marketing } \\
\text { programme targeted at employees. }\end{array}$ & 11 & 20 & 1 & $\mathbf{0}$ & $\mathbf{0}$ \\
\hline 35 & $\begin{array}{l}\text { What customers hear about this company and what } \\
\text { we hear internally are the same. }\end{array}$ & 11 & 17 & 2 & 2 & $\mathbf{0}$ \\
\hline 36 & $\begin{array}{l}\text { In order to be rewarded, I need to live the values } \\
\text { of this organisation. }\end{array}$ & 11 & 16 & 1 & 4 & $\mathbf{0}$ \\
\hline 37 & $\begin{array}{l}\text { Non-financial rewards are given to those } \\
\text { employees that live the brand of the organisation. }\end{array}$ & 11 & 15 & $\mathbf{0}$ & 5 & 1 \\
\hline 38 & $\begin{array}{l}\text { Values which I admire in this organisation are: } \\
\text { respect and trust. }\end{array}$ & 11 & 14 & 4 & 2 & 1 \\
\hline 39 & I’m satisfied in my job. & 10 & 18 & 1 & 2 & $\mathbf{1}$ \\
\hline 40 & $\begin{array}{l}\text { Keeping employees motivated is something this } \\
\text { company is really good at. }\end{array}$ & 10 & 17 & 1 & 4 & 0 \\
\hline 41 & $\begin{array}{l}\text { Internal marketing programmes always involve } \\
\text { two-way communication between employees and } \\
\text { senior management. }\end{array}$ & 10 & 17 & 3 & 2 & $\mathbf{0}$ \\
\hline 42 & $\begin{array}{l}\text { This company measures me according to how I } \\
\text { live the brand of the organisation. }\end{array}$ & 9 & 18 & 1 & 4 & $\mathbf{0}$ \\
\hline 43 & This company pays well. & 8 & 17 & 5 & 1 & 1 \\
\hline 44 & $\begin{array}{l}\text { Employees play an active role in the development } \\
\text { and implementation of such programmes. }\end{array}$ & 7 & 20 & 4 & 1 & $\mathbf{0}$ \\
\hline 45 & $\begin{array}{l}\text { Financial incentives are offered to employees that } \\
\text { live the brand of the organisation. }\end{array}$ & 6 & 17 & 3 & 6 & $\mathbf{0}$ \\
\hline 46 & $\begin{array}{l}\text { This company makes an effort to understand the } \\
\text { individual needs of their employees. }\end{array}$ & 5 & 20 & 3 & 3 & 1 \\
\hline
\end{tabular}


Table 4: Employee branding evidence

\begin{tabular}{|c|c|c|c|c|}
\hline & Company 1 & Company 2 & Company 3 & Company 4 \\
\hline Company, conference or induction videos & $\checkmark$ & $\checkmark$ & $\checkmark$ & $\checkmark$ \\
\hline Vision and value statements & $\checkmark$ & $\checkmark$ & $\checkmark$ & Limited \\
\hline Team memorabilia or pictures & $\checkmark$ & $\checkmark$ & $\checkmark$ & Limited \\
\hline A pub or place to gather & $\checkmark$ & $\checkmark$ & $\checkmark$ & $\checkmark$ \\
\hline Uniforms, branded clothing or give-aways & $\checkmark$ & $\checkmark$ & $\checkmark$ & $\checkmark$ \\
\hline Branded stationery (office items, brochures) & $\checkmark$ & $\checkmark$ & $\checkmark$ & $\checkmark$ \\
\hline Internal notice boards with communication & $\checkmark$ & $\checkmark$ & $\checkmark$ & $\checkmark$ \\
\hline $\begin{array}{l}\text { Feedback mechanism to management, for example a suggestion box, } \\
\text { email, monthly forums, focus groups or surveys }\end{array}$ & $\checkmark$ & $\checkmark$ & $\checkmark$ & $\checkmark$ \\
\hline Internal company initiatives indicating employee branding & $\checkmark$ & $\checkmark$ & $\checkmark$ & $\checkmark$ \\
\hline Employee / Employer Awards & $\checkmark$ & $\checkmark$ & $\checkmark$ & $\checkmark$ \\
\hline Intranet is specifically used to obtain employee branding & Limited & $\checkmark$ & $\checkmark$ & $\checkmark$ \\
\hline
\end{tabular}

It was proposed that companies which successfully obtain employee commitment to living the brand of the organisation have the following characteristics:

1. The companies make employee branding a key business priority

This proposition was found to be true in the study as shown in Tables 1 to 4 . This confirms the findings of James (2000), Mitchell (2002) and Beagrie (2003) that in order for employee branding to occur it has to be made a key business objective. The results clearly show that employees perceived the topic of employee branding to be 'a top business priority'. Employees believed that it is achieved if management 'walked the talk' which was supported by Welbourne (2003).

One finding which became evident in the study that was not found in the literature was that a brand must be perceived by employees as valuable. This is shown in Table 3 where the statement, 'a brand is a valuable asset' is ranked top. Both Kotler (1997) and Keller (2003) alluded to the value of a brand and the benefits associated with them.

Czaplewski et al. (2001) suggest that employees want to know how their work fits into the broader scheme of business operations and understand and believe in the goal that they are working toward. This was particularly evident in that employees were clearly able to articulate the benefits of obtaining employee commitment to living the brand of the organisation, namely an addition to building brand differentiation in a cluttered market place. The construct 'competitive advantage and differentiation' is ranked third most important in Table 2.
Furthermore it was proposed by Mullich (2003) that human capital branding can only occur when employees can see that their efforts dovetail with the company's corporate goals. Table 3 shows that employees ranked the statement 'I understand how I contribute to the overall success of the company' in the top third of Table 3. Twenty six of the 32 respondents agreed with the statement 'we have workshops to ensure that our department's goals are in line with those of the company's'.

This proposition is therefore reworded as 'The companies make living the brand a key business objective' and is accepted as one of the key factors in obtaining employee commitment to living the brand of the organisation.

2. The companies communicate and live by a clear set of values to their employees,

This proposition was supported in Tables 2 and 3, although many employees perceived the idea of communicating a clear set of values as part of the first proposition i.e. living the values of the organisation is a key business priority. It was proposed by Ind (2004) that employees have to believe in the values of the organisation, implying that if employees can believe in the values, the chances are high that they would live them. It was suggested by James (2000), Mitchell (2002) and Beagrie (2003) that employees needed to be made aware of the vision, values and 'bigger picture'. The case studies show in all four tables that this is a critical aspect for obtaining employee commitment to living the brand of the organisation. It is recommended that this combined theme be incorporated into the first proposition 'The companies make living the brand a key business objective' as this captures the essence of communicating the values and living by them. 
3. The companies compete for talented employees and focus on their needs

Proposition 3 was not totally supported by the study. Czaplewski et al. (2001) proposed that an organisation must compete for talent. Aspects of the original proposition are valid but the idea of competing for talented employees is not directly supported (see Table 3). Employees believed that having a culture and value set which viewed employees as the most important asset, and whose development is a key issue, was far more important to them than trying to employ the best employees. This was evident in Table 3 particularly where 'I am encouraged to learn and develop' ranked second overall. There was also strong evidence for this in Table 2.

Czaplewski et al. (2001) state that companies need to know their internal customers, i.e. employees and focus on their individual needs. Table 3 has the focus on employee individual needs as least evident of all items. Table 2 shows that providing an environment which allowed employees freedom to operate, where personal responsibility and accountability was encouraged, was seen as more important. In addition, building a sense of belonging, where pride, commitment and loyalty were the outputs was something which all employees wanted to 'buy-into'. Tables 2 and 3 supported this theme and it is thus an important factor in obtaining employee commitment to living the brand of the organisation. The importance of employee loyalty was highlighted by Fram and McCarthy (2003) and Larsen (2003). Statements like, 'I feel loyalty to this organisation' and 'I'm proud to wear company branded items' are ranked in the top ten items of Table 3 and show that the authors are correct in saying that obtaining employee loyalty is critical to employee commitment to living the brand of the organisation.

The varying degree of support for this proposition has led to the proposition being divided into two in order to better represent the key factors:

- $\quad$ The companies must create a culture and value set that views employees and their training and development as central to the culture of the organisation.

- The companies must create a sense of belonging through pride, commitment and loyalty, whilst encouraging personal responsibility and accountability.

4. The companies have an internal employee branding programme which builds employee loyalty through informing, motivating, energising and engaging employees.

Results from Tables 2 and 3 together with the discussion in the previous proposition clearly show that loyalty is a key factor in obtaining employee commitment to living the brand of the organisation. Robbins (1998) states that it was important to influence the factors of motivation, i.e. use goals, feedback and link rewards to performance. Tables 2 and 4 show that all these factors were evident in the various organisations and therefore important in the overall scheme of obtaining employee commitment to living the brand of the organisation.

Similarly Brauer in Larsen (2003) noted that in order to achieve the output of loyalty, the inputs to loyalty i.e. care and concern, fairness at work, communication, accomplishment and trust are necessary. The study showed, in the tables, that many of these inputs were evident. However, even more interesting was the fact shown in Table 3 that satisfaction does not equal loyalty, i.e. employees can be unsatisfied in their work but still remain loyal to the company. This is seen in Table 3 where job satisfaction ranks poorly, whilst loyalty ranks highly and is seen as important. This is congruent with the findings by Sutherland and Jordaan (2004) where they found that job satisfaction is unrelated to both loyalty, as measured by intention to stay with the organisation, and commitment. Job satisfaction needs to be re-examined more fully in the knowledge era, where the psychological contract has changed profoundly (Armstrong, 2000).

The idea that an internal marketing programme was needed which included employees in the development and implementation thereof was not evident. All factors relating to this, ranked in the last $10 \%$ of Table 3 , showing that it was not a key factor in obtaining employee commitment to living the brand of the organisation. Tables 2 and 3 show that obtaining employee commitment to living the brand of the organisation, is primarily a top down approach driven from a senior management perspective.

As part of this proposition Pine and Gilmore (1998) noted the importance of staging company experiences or events as being critical to achieving loyalty, pride and commitment. Table 2 ranked 'it is usual for the company to hold themed events for employees' in the top 10 factors, proving the importance of this factor. Similarly it was proposed by Mitchell (2002) that internal and external marketing have to be linked. Table 4 in particular highlights the number of ways that these companies use to reinforce the brand to employees.

Given the large focus on loyalty, commitment and motivation and the fact that many themes are included in this proposition which overlap with others from other propositions, this proposition has been split into two themes:

- $\quad$ The companies spend a great deal of effort and energy encouraging employee commitment to living the brand of the organisation. The companies have a multidimensional approach, with many activities contributing to the overall cause.

- The companies must create a sense of belonging through pride, commitment and loyalty, whilst encouraging personal responsibility and accountability

5. The companies integrate measurement and reward criteria into their overall performance management system to track, evaluate and reward employee commitment to living the brand of the organisation 
It was proposed by Mullich (2003) that employees need to be evaluated, rated and given feedback on how they performed against their goals and the company's goals. This was supported by Welbourne (2003) who believed that in order for employee engagement to be a success, organisations need to measure employee engagement frequently and in multiple ways. The results from Tables 2 and 3 show that this is the case in these companies. The study found that employees at all the companies were being measured according to how they live the brand of the organisation. Interestingly though, the statement 'this company measures me according to how I live the brand of the organisation' was ranked poorly in Table 3 because employees only 'agreed' to the statement and didn't 'strongly agree'. This point was further investigated in the interviews with the Human Resource Managers and the reason identified for this was the fact that living the brand of the organisation only counted for a small portion (usually $10 \%$ ) of their overall performance assessment. It was never measured in isolation.

This proposition is therefore supported as performance management practices and the measurement of employee commitment to living the brand of the organisation is a key factor. It is important to note that this is part of a larger performance management approach, rather than a stand alone assessment.

6. The companies monitor company culture (beliefs and values) on an ongoing basis and are prepared to effect changes when necessary

This proposition was not accepted by the study. Companies tended to create a culture and keep the culture relevant rather than monitor it and make changes sporadically. It was proposed by Williams (1989) that organisational culture includes patterns of behaviour in the organisation, i.e. the rites, rituals and symbols. The statement, 'this organisation has a unique culture that I identify with' was ranked $6^{\text {th }}$ overall in Table 3 and showed that organisational culture is an important concept for organisations trying to obtain employee commitment to living the brand of the organisation.

A significant observation from the results was that employees from all the organisations which participated in the study were used to continuous change. The statement 'change is something we are used to' was ranked $3^{\text {rd }}$ in Table 3. Table 3 showed that all of the companies implementing change generally did it professionally using change agents, focus groups, communication sessions etc. Creating a culture and keeping it relevant are therefore key factors in obtaining employee commitment to living the brand of the organisation. It is suggested that this proposition be merged into theme four, companies must create a culture and value set that views employees as the most important asset in the company.

Factors identified as not being critical to obtaining employee commitment to living the brand of the organisation. In contradiction to the literature it was found that the following factors are not critical for internal branding purposes.

1. Meeting the individual needs of employees. It was proposed by Robbins (1998) that one of the key criteria in influencing employee motivation levels were recognising individual differences and meeting the individual needs. Czaplewski et al. (2001) state that in order to obtain employee commitment to living the brand of the organisation, companies need to focus on their internal customers' individual needs. Evidence for the rejection of this is that the statement, 'this company makes and effort to understand the individual needs of their employees' was ranked last in Table 3. The study has shown, in contradiction to the literature, that these companies implement a top down approach rather than basing the intervention on individual employee needs. This is an important finding for human resource management where autonomy and freedom are much vaunted. This study indicates that a strong culture is formed that employees are then expected to buy into.

2. Financial reward. Much literature and especially Herman and Gioia (2000) state that compensation and benefits are a key factor considered by employees. It was therefore proposed that financial rewards would be a critical success factor. Table 3 shows that this was not the case as pay, and financial reward for living the brand were found to be poorly ranked, being two of the bottom four factors. Given all the evidence it is proposed that although financial reward is not a key determinant of obtaining employee commitment, but employees must deem their package as market-related. Pay cannot make up for other aspects of internal branding activities.

3. Job satisfaction. It is suggested by Cormack (2003) that satisfaction levels, particularly job satisfaction, play an essential role in motivating employees to perform. Table 3 shows that the statement 'I am satisfied in my job' ranked in the last 10 percent. This means that job satisfaction is not a determiner of employees living the brand. As discussed above, job satisfaction and its relationship to the many other performance variables discussed historically in the human resource literature, need to be re-examined in the $21^{\text {st }}$ century.

4. Employee input to internal branding development and implementation. It is proposed by Czaplewski et al. (2001) and Beagrie (2003) that employee involvement in the development and implementation of employee branding initiatives is critical. Table 3 clearly showed that the statements relating to these factors ranked in the last 10 percent of the table. The evidence again suggests a top down approach initiated by senior management to be effective and that employee involvement in the design of the initiatives is not necessary. 


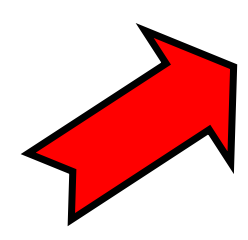

\section{Measure}

\section{Make living the brand a key business objective}

- A brand must be seen as valuable

- Communicate a clear set of values

- Senior management must 'walk the talk'

- The benefits must be understood by employees

- Employees must understand how they contribute to the overall success of the company



- Every employee must be measured according to how they live the brand of the organisation

- Employee commitment must be measured as part of employees overall performance appraisal

- Recognition and reward should be part of the organisation's culture

\section{Multi-dimensional approach}

- Spend a great deal of effort and energy encouraging employee commitment to living the brand of the organisation

- Internal and external marketing must be linked

- Make the brand come alive \& create an emotional link

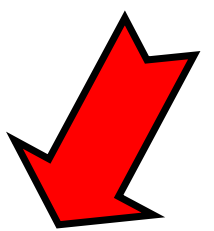

\section{Communication}

\section{Create a sense of belonging through loyalty, pride and commitment}

- Employees must have freedom to perform

- Employees must be self motivated

- The company must hold events or functions

- Loyalty motivators must be evident
- Use an array of communication material

- Try various methods and channels

- Communicate the theme at every opportunity

- Top down approach

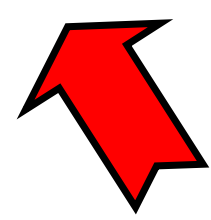

\section{Create a culture \& value set where employees are valued}

- Training \& development must be central to the

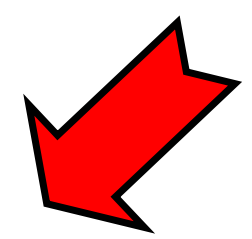
culture

- Employees must feel that their values are similar to those of the organisation

- Organisational culture must be kept relevant and actively managed

Figure 1: Employee branding model: A self reinforcing cycle 
These four factors are an important outcome of this exploratory study as they challenge some fundamental principles of human resource management.

\section{Conclusion}

The objective of the study was to obtain empirical evidence on the critical success factors in order to provide a framework for managers trying to encourage their employees to live the brand of the organisation. From the literature and the results of the four case studies an employee branding model has been developed to serve as a framework for implementing such an initiative.

The model is based on the idea of a self reinforcing cycle of six key components that the human resource managers should attend to when setting out to obtain employees' commitment to living the brand of the organisation. The model implies that the organisation has to practice all six components in an integrated manner as they depend on one another, i.e. a company must make employee branding a key business objective which requires a multi dimensional approach, that needs excellent communication to create a culture and value set where employees are valued, this creates a sense of belonging through loyalty, pride and commitment, which has to be measured if the organisation is going to make employee branding critically important. In other words this is a total organisational intervention where each component is inter-linked. This model is an example of where an integrated approach yields results in excess of the individual components. Under each component in the model the critical elements to achieving that component as derived from the empirical research are detailed. For example, in order for a company to make employee branding a key business objective they have to ensure that their staff understand that a brand is valuable, clearly communicate the values of the organisation, senior management must 'walk the talk', employees must understand the benefits of employee branding and finally employees must know how they contribute to the overall success of the company.

Managers wishing to obtain employee commitment to living the brand of the organisation need to pay attention to all aspects of figure one, not just one component of the model. This unfortunately means that this is not a "quick fix" solution. It is important to note that obtaining employee commitment to living the brand of the organisation is not only a marketing function or a human resource function, it's a total organisational intervention, where one element depends on the other: inter-linked and co-dependent.

Employee branding is a way human resource managers can assist in differentiating the company and its products, and increasing the value of brands. Employee behaviour can ultimately destroy brand equity or build it and hence deserves serious attention by management. It is hoped that this study has provided strong evidence as to how companies should implement an organisation-wide intervention to enable their employees to increase brand value.

\section{References}

Armstrong, M. 2000. Performance management: Key strategies and practical guidelines. 2nd Edition. London: Kogan Page Ltd.

Bascal, R. 2000. Performance management. New York: McGraw-Hill.

Beagrie, S. 2003. 'How to influence employee behaviour through internal marketing’, Personnel Today, August: 35.

Bendapudi, N. \& Bendapudi, V. 2005. 'Creating the living brand’, Harvard Business Review. 82(5):124-128.

Bryman, A. 1989. Research methods and organisation studies. London: Routledge.

Copeland, J. 2000. 'Attracting and keeping the best people'.[online] URL:

http://accounting.pro2net.com/x27635.xml. Accessed 6 March 2004.

Cormack, S. 2003. 'Perceived performance motivators within the South African retail banking industry'. Unpublished MBA Research Report, Johannesburg: University of Witwatersrand.

Czaplewski, A.J., Ferguson, J.M. \& Milliman, J.F. 2001. 'Southwest Airlines: How internal marketing pilots success’, Marketing Management, 10(3): 14-18.

Das, S. 2003. 'Vacant or engaged?' Employee Benefits, March:24 -28.

Drummond, G. \& Ensor, J. 1999. Strategic marketing: Planning and control. Oxford: Butterworth-Heinemann,.

Fram, E.H. \& McCarthy, M.S. 2003. 'From employee to brand champion’, Marketing Management, 12(1): 24-30.

Greatplacetowork. 2004. [online] URL: http://www.greatplacetowork.com. Accessed 6 March 2004.

Herman, R.E. \& Gioia, J.L. 2000. How to become an employer of choice. Winchester Virginia: Oakhill Press.

Ind, N. 2004. Living the brand. $2^{\text {nd }}$ Edition. Great Britain: Kogan Page.

James, D. 2000. 'Don't forget staff in marketing plan', Marketing News, 34(6):10-12.

Keller, K.L. 2003. Strategic brand management - Building, measuring, and managing brand equity. 2nd Edition. Upper Saddle River, New Jersey: Prentice Hall.

Kotler, P. 2003. Marketing management. 11th Edition. Upper Saddle River, New Jersey: Prentice Hall.

Kotter, J.P. 1995. 'Leading change: Why transformation efforts fail', Harvard Business Review, 73(2): 59-67. 
Larsen, L. 2003. Employee Loyalty Survey, Journal of People Dynamics, November \& December, 10-12.

Leedy, P.D. \& Ormrod, J.E. 2001. Practical research: Planning and design. 7th Edition. Upper Saddle River: Merrill Prentice Hall.

Loehr, J. \& Schwartz, T. 2003. The power of full engagement, managing energy not time, is the key to high performance and personal renewal. New York: Free Press.

McDermott, J. 2002. 'Employee incentives that work', CabinetMaker, 5(16): 42-44.

Miller, J.F. 2002. 'Motivating people', Executive Excellence, 12 (19): 15.

Mitchell, C. 2000. 'Selling the brand inside', Harvard Business Review, 80(1):99-105.

Mullich, J. 2003. 'Get in line’, Workforce, 82(13):43-46.

Payne, A., Christopher, M., Clark, M. \& Peck, H. 2001. Relationship marketing for competitive advantage. CIMA, Kent:Butterworth-Heinemann.

Pine, II, J. \& Gilmore, J.H. 1998. 'Welcome to the experience economy’, Harvard Business Review, 76(4):97107.

Robbins, S. P. 1998. Organisational behaviour. 8th Edition. New Jersey: Simon \& Schuster.

Simms, J. 2003. 'HR or marketing: Who gets staff on side?', Marketing (UK), July: 23.

Spark, J. 2004. 'Recognise your brand's true value', Executive Business Brief, 9(2):6-7.

Stake, R. 1995. The art of case study research. Thousand Oaks: Sage.

Sutherland, M. \& Jordaan, W. 2004. 'Factors affecting the retention of knowledge workers', SA Journal of Human Resources Management, 2(2): 55-64.

Yin, R.K. 1984. Case study research - Design and methods. Applied Social Research Methods Series Vol. 5. California: Sage Publications.

Welbourne, T. 2003. 'Employee engagement, doing it vs. measuring it', Journal of People Dynamics, November \& December: 30-31.

Williams, A. 1989. Changing culture. Great Britain: Dotesios Printers Ltd. 